Check for updates

The BMJ

Cite this as: $B M J 2020 ; 371: \mathrm{m} 4950$ http://dx.doi.org/10.1136/bmj.m4950 Published: 23 December 2020

\title{
Covid-19: UK regulator approves lateral flow test for home use despite accuracy concerns
}

\section{Elisabeth Mahase}

The UK's regulator has approved the Innova lateral flow covid-19 test for people to self-administer despite warnings from some testing experts that it is inaccurate and may give people a false sense of security.

The Medicines and Healthcare Products Regulatory Agency (MHRA) announced that it had issued authorisation to the Department of Health and Social Care on 23 December to allow the use of the antigen lateral flow test for home testing to "detect infection in asymptomatic individuals."

"A negative test result means that the test has not detected the presence of the covid-19 virus, at the time the test was taken," it said. "Anyone receiving a negative test result should continue to follow the latest guidance for their area."

This comes after Jon Deeks, professor of biostatistics at the University of Birmingham, shared unpublished results on social media from the mass testing programmes at the University of Birmingham and Scottish universities suggesting that the lateral flow tests had a sensitivity of just 3\% (the proportion of people with covid-19 who tested positive) and that $58 \%$ of the positives were false positives. ${ }^{1}$ Deeks, who also leads the Cochrane Collaboration's covid-19 test evaluation activities, said that the results would be available as a preprint soon.

Previous data from the Liverpool mass testing pilot programme found that lateral flow tests detected just $48.89 \%$ of covid-19 infections in asymptomatic people when compared with a polymerase chain reaction (PCR) test. It also found that the Innova Lateral Flow SARS-CoV-2 antigen test failed to detect three in 10 cases with the highest viral loads. ${ }^{2}$

\section{Mass asymptomatic testing}

The MHRA said that the authorisation followed a "robust assessment procedure when considering applications for exceptional use of a medical device," but it did not provide any details on how accurate the tests were.

Although the government has pushed forward with the rollout of mass asymptomatic testing around England and in schools, a minister at the Department of Health and Social Care admitted that mass swab testing was "not an accurate way of screening the general population" and could provide false reassurance, in a letter seen by The BMJ. ${ }^{3}$

However, speaking at a Science Media Centre briefing on 23 December, John Bell, regius professor of medicine at the University of Oxford, said, "I think the way to think about these [lateral flow] tests is that everyone you catch with these tests is someone who would not normally be caught because they don't have symptoms.

"Every successful positive you get with these tests is a win, and as a result there is a great argument for testing as many people as you can and catching all those people. Liverpool has some great data on exactly that ...The lateral flow test measures infectiousness, not bits of RNA in your nose and mouth [like the PCR test], and as a result you would expect it to have a very different set of results."

1 Armstrong S. Covid-19: Tests on students are highly inaccurate, early findings show. BMJ2020;371:m4941. https://www.bmj.com/content/371/bmi.m4941.

2 Wise J. Covid-19: Lateral flow tests miss over half of cases, Liverpool pilot data show. BM/2020;371:m4848. doi: 10.1136/bmj.m4848 pmid: 33323368

3 Mahase E. Covid-19: Mass testing is inaccurate and gives false sense of security, minister admits. BMJ2020;371:m4916doi: 10.1136/bmj.m4916.

This article is made freely available for use in accordance with BMJ's website terms and conditions for the duration of the covid-19 pandemic or until otherwise determined by BMJ. You may use, download and print the article for any lawful, non-commercial purpose (including text and data mining) provided that all copyright notices and trade marks are retained. 